\title{
7
}

\section{Kinship, poor relief and the welfare process in early modern England}

\author{
Sam Barrett
}

\section{Overview - the 'problem' of kinship}

Historiographical writing on the depth and functionality of kinship in early modern England is limited. It is also contradictory. On the extent and depth of kinship networks, for instance, early commentators such as Peter Laslett were clear that English households tended to be relatively small and simple and that, because of demographic constraint (migration, 'background' mortality, epidemic mortality and relatively late marriage ages), such families were located within relatively shallow kinship networks. ${ }^{1}$ Microsimulation exercises appeared to confirm this view, suggesting that 'achievable' levels of kinship in most localities remained low throughout the early modern period. ${ }^{2}$ Other early commentators, focusing on particular social, religious or regional groups, were not so sure. Lawrence Stone suggested that, notwithstanding negative demography, nominal kinship networks amongst the aristocracy and gentry could be both deep and extensive, ${ }^{3}$ while Gilbert noted that nonconformist groups such as Quakers were tied into very deep kinship connections which could be used in business, an idea that has become a commonplace of the Industrial Revolution literature. ${ }^{4}$

More recent analysis of the extent and depth of kinship networks has not proved any less contradictory. Painstaking empirical work by Cooper and Donald has revealed that in suburban Exeter the extent of local kinship networks (and of kinship co-residence) is substantially understated using conventional census ${ }^{m}$ annalytsis 9781526137869 
because of the tendency for many of those standing in contractual relationships to local families to in fact be kin by blood or marriage.$^{5}$ Reay has also sought to question the idea of shallow kinship networks. Focusing on rural villages in nineteenth-century Kent he argues that while extended families were comparatively rare, well over one half of all families by 1851 were related to at least one other, that perhaps a further 10 per cent who had no kin in their village nonetheless had kin in immediately adjacent villages (which meant only small distances to travel given the small size of southern parishes) and that even if complex families containing kin were relatively rare, kin nonetheless lived in proximate residence to each other, creating de facto extended families. ${ }^{6}$ Other commentators have found less to take issue with in the views of Laslett. Keith Wrightson, for instance, has calculated that in the Essex village of Terling, only 33 per cent of all families had kinship connections by blood or marriage with others in the same community. ${ }^{7}$ In mid-nineteenth-century south-east Surrey, Evelyn Lord found that for ten rural communities kinship density was at best on a par with, and usually much lower than, the kinship densities identified by Wrightson for Terling well over 100 years earlier. ${ }^{8}$

The purpose of my chapter is not to address this literature on the extent and depth of kinship directly, though a quantitative measure of kinship density is important for establishing the limits of potential kinship involvement in the economy of makeshifts. Rather, I think that historiographical division over the extent and depth of kinship networks feeds directly into division over the functionality of kin in the welfare arena and particularly over the question of whether (and if so at what level) kin provided welfare in substitution for, or support of, the poor law and charity. ${ }^{9}$ On the one hand, commentators such as Cressey, Fissell, King and Thane suggest that kin must have been an important part of the economy of makeshifts, a way for poor people to avoid poor relief or a means to supplement poor relief which, as King shows, was always and everywhere inadequate to hold body and soul together. ${ }^{10}$ Cressey, for instance, concludes that for families 'most of the time their dealings were limited to those closest to them but the potential existed to bring even distant and latent kin into a close and effective [welfare] relationship'." ${ }^{11}$ Fissell for Bristol and King for Yorkshire provide some support for this idea. They show that those obtaining medical or other relief were disproportairntatel 9781526137869 
those who lacked dense kinship networks in their locality. ${ }^{12}$ In these cases, the poor law might act as a partial substitute for kinship networks, though neither author seems to provide support for the contentions of Peter Laslett that weak kinship networks necessarily generated more generous or more encompassing poor law systems. ${ }^{13}$

Other contributors to the debate have argued that many local poor law authorities tried to create a care partnership between (often stretched) kinship networks and community resources. Both Thane and Botelho suggest that the elderly in the eighteenth and nineteenth centuries were likely to be subject to these sorts of implicit agreements as their working capacity was curtailed, and in the absence of formal retirement agreements of the sort that we see in some continental countries. ${ }^{14}$ The poor law, for instance, could pay rent for elderly people living with relatives, effectively sharing the full cost of providing for such old people and giving poor families valuable cash flow. Lynne Hollen Lees suggests that such partnerships, aimed at ensuring the survival of the family unit and the coherence of the kinship and neighbourhood networks of poor people, might have been the norm and could, at least until the nineteenth century, guarantee a basic level of community support to poor people within their kinship networks for long periods of time. Using vestry minute evidence from nineteenth-century Lancashire, one of the most parsimonious of all English counties in relief levels and eligibility, King supports this idea. ${ }^{15}$

There are, however, alternative and competing lines of historiography. Sandra Cavallo, for instance, echoes Michael Anderson in suggesting that family members often conflicted over the issue of welfare and that where families did provide welfare the respective obligations of donor and recipient were strictly limited by negotiation. In fact, she suggests, institutions played a large part in the coping strategies of poor people, and might effectively act as surrogate kin. Her data is for Italian communities, but the lessons are probably portable. ${ }^{16}$ Meanwhile, David Thomson, dealing with the experience of paupers in the initial decade of the new poor law in Bedfordshire, argues that despite well-known legal provisions that some of the kin of paupers were obliged to care for them where they had the means to do so, in practice welfare was a community rather than a familial responsibility. Either because they were not able, or because they chosse Brrot to, 9781526137869 
families did not form either a large or consistent part of the welfare process. ${ }^{17}$ Crowther likewise sees a decisive shift in the balance of provision during the nineteenth century (though with counties such as Kent continuing to enforce the 'liable relative clause' which was little changed by the 1834 Poor Law Amendment Act) as the economic position of families moved decisively against offering material support at times of life-cycle stress. ${ }^{18}$ McIntosh traces a decisive negative shift in family support for paupers at a much earlier date. She suggests that 'A contrast between formal and informal or between public and private care would likewise have puzzled Elizabethans' and shows that in late sixteenth-century Hadleigh over one-third of all people in receipt of welfare also had fairly extensive and economically secure local kinship networks. By the late seventeenth century, however, her own evidence and that of Wales and Newman Brown suggests that for certain groups of the poor the community was becoming the main plank of welfare and kinship was being relegated to the backwaters of the economy of makeshifts. ${ }^{19}$ These differences over the timing of any transition in the role of kin are important, and would be magnified considerably if we had more numerous local studies available. However, the stark contrast between the two ends of the historiographical spectrum on the role of kinship in the economy of makeshifts is clear to see.

Of course, there are many good reasons for these different levels of contradiction. Kinship density could change rapidly in any locality (due to mortality crises, for instance) as well as experiencing longer-term trends. It is thus difficult, even with the best of sources, to trace the exact dynamics of kinship in a given community over time, and even more difficult to put community experiences together in order to pin down regional typologies of either kinship depth or functionality. ${ }^{20} \mathrm{~A}$ further problem, however, is that reconstructing the density of kinship and its functionality is problematic given the level and quality of English record keeping and survival. English sources are considerably less rewarding than those on the continent, ${ }^{21}$ and for any individual community we have to undertake complex multiple source record linkage in order even to begin uncovering kinship networks and reading their meaning. The potential pitfalls in this sort of record linkage are numerous - kinship connections tend to get lost as we link between sources of different types; considerable numbers of inlaws, stepchildren, half-children or adopted childrensacoinpliteate 781526137869 
decisions on who is really (and functionally) related to whom; and repeated movements between communities could create an extensive localised kinship network which the historian simply does not detect when looking at individual communities ${ }^{22}$ - but the rewards are considerable.

This chapter will use family reconstitutions linked to a range of supplementary data for six communities in the West Riding during the eighteenth and nineteenth centuries, in order to reconstruct the depth of local and regional kinship networks and then to elaborate the place of kinship in the economy of makeshifts. Utilising over 18,000 discrete family histories I will suggest that kinship densities in the West Riding woollen district were very high, that we can detect a broad inverse relationship between kinship density and community level poor law spending, as Fissell and King have suggested, and that there was a broad positive relationship between kinship density and receipt of charity. However, the existence of such a relationship does not mean that those with dense kinship links never received poor relief. I will demonstrate that the poor law often provided resources to those with kin in response to sudden crisis such as illness, giving the kinship group time to marshal the material and human resources which kept their relatives off longer-term relief. Finally, I will use narrative evidence to try and pin down the character of the support that kinship networks were able to offer in the late eighteenth century.

\section{Places and sources}

The West Riding of Yorkshire is certainly the most fully reconstituted of all eighteenth- and nineteenth-century counties. By the mid-1990s no fewer than 23 townships in the county had been subject to family reconstitution, and this chapter uses some of these reconstitutions and contributes to the stock with new studies. It covers six townships in four large parishes. Tong and Cleckheaton (1801 populations 1,637 and 1,336 respectively) were part of the very large parish of Birstall and were reconstituted by Hartley Thwaite. They have been subject to extensive demographic analysis as part of the 26-reconstitution sample used by Wrigley and Schofield in 1997. ${ }^{23}$ Horsforth in Guiseley parish (1801 population 2,099), Otley (1801 population 2,014) and Afmleyroathd 9781526137869 


\section{The poor in England}

Bramley (1801 populations 2,695 and 2,562 respectively ${ }^{24}$ ) were townships in the western part of the sprawling parish of Leeds and were reconstituted by the author as part of a study of kinship in the woollen and worsted districts of the West Riding. ${ }^{25}$

This collection of townships makes an ideal framework for the study of the role of kinship in welfare provision for several reasons. First, the townships were all in relative proximity to each other, allowing us to talk (albeit not definitively) about localised rather than simply community-based kinship networks. The townships were also staging points for migrants on the way to, and returning from, Leeds itself, easing some of the uncertainties of record linkage created by heavy short distance migration in early modern communities. ${ }^{26}$ A second reason for the suitability of this collection of townships is that while they are all nominally located in the woollen district of the West Riding, they had very different occupational structures, allowing a contrast of the scale, depth and functionality of kinship networks across a number of different socio-economic typologies which may have wider echoes with communities elsewhere. There is not the space here to conduct a detailed anatomisation of any one community, and in any case both the general and the specific occupational and economic history of the West Riding and its individual townships has been drawn by others. ${ }^{27}$ Briefly, though, Horsforth and Otley were centres of woollen cloth production organised under the artisan system whereby essentially small-scale producers combined, at family level, textile production with farming and other income generation strategies. Armley combined agricultural production with textile production organised through the putting-out system, which drew around one-third of male workers in the town into a proletarian relationship with Leeds merchants by the 1780s at the latest. However, as Mr James Ellis testified before the 1806 enquiry into the state of the woollen industry, the township also had its fair share of resident master manufacturers who, as well as spinning and weaving on their own account, also put out work to other families in Armley and its surrounding hamlets. ${ }^{28}$ Bramley was a centre for the preparation of wool and the finishing of woollen cloth, with scribbling, carding and fulling mills surrounded by independent yeomen clothiers often maintaining substantial farms and organising putting-out networks in other townships. Tong and Cleckheaton were more balanced villages, combining some mining and quarrying with textile production, agriceltareetand 9781526137869 
especially in the case of Tong, service industries such as baking and milk production for surrounding industrial townships. ${ }^{29}$

However, the most compelling reason for looking at these townships is the volume and clarity of the archival collections relating to them. While none of the townships have continuous parish register sources, the Bishops' Transcripts are excellent and more than compensate for the gaps. Moreover, while these townships, like the rest of the West Riding, have considerable numbers of nonconformist places of worship, survival of the nonconformist registers is really very good. ${ }^{30}$ More than this, though, the reconstitution evidence can be linked to poor law accounts, charity records, diaries and a variety of other material, such as the credit book of the Bramley scribbling miller Joseph Rogerson, that can throw light on the complex patchwork of the economy of makeshifts in this part of the West Riding. ${ }^{31}$

\section{Kinship and the economy of makeshifts in Yorkshire}

To locate the relationship between the economy of makeshifts and kinship in these communities, we must initially turn to the width and depth of local kinship networks. As one might expect of this subject, historians agree on neither the best way to measure kinship connections nor on the nature of the relationship that must exist for a person to be regarded as part of a kinship group. ${ }^{32}$ However, Table 7.1 uses family reconstitution evidence to quantify the depth of kinship networks in the six communities for the whole period 1700-1820, employing a cut-off point at the level of first cousins to determine what does and does not constitute kinship. Clearly, whatever the socio-economic composition of the individual townships, the extent of kinship networks was considerable. The levels of interrelationship found here are twice or three times those found in Essex or Surrey, though they are also consistent with kinship densities detected by King and by Coster for other Yorkshire communities. ${ }^{33}$

There was a broad tendency for those communities with the greatest reliance on rural industry to have the densest kinship networks from an early date. This makes sense. As local witnesses before the 1806 enquiry into the state of the woollen industry testified, putting-out jobs were plentiful and there was still an expectation that young men in this area of the West Rielingarcoutld 9781526137869 
Table 7.1 Kinship density (\%) in six West Riding towns, 1700-1820

\begin{tabular}{lcccc}
\hline Place & Related to 0 & Related to 1 & Related to 2 & Related to $3+$ \\
\hline Otley & 18 & 22 & 35 & 25 \\
Horsforth & 19 & 25 & 26 & 30 \\
Tong & 24 & 30 & 26 & 20 \\
Cleckheaton & 27 & 28 & 29 & 16 \\
Armley & 23 & 26 & 20 & 31 \\
Bramley & 29 & 32 & 20 & 19 \\
\hline
\end{tabular}

climb to achieve economic independence. James Ellis noted, 'I was not kept constantly to weaving and spinning; my master fitted me rather for a master than a journeyman.' More importantly, the woollen industry provided plenty of jobs for other members of the family, even as hand spinning came to be replaced by mechanised spinning. Ellis also noted in response to questions about the treatment of raw wool 'that we employ inferior people, women and children, to do, any person may do that'. ${ }^{34}$ The economic imperative to move longer distances that we might see in the midlands or the rural south was thus missing and consequently kinship densities were higher. This did not mean, though, that families in these villages had few kinship links in surrounding villages. Many of those with no apparent connection in one township appear to have had connections in another not too far away, while most of those with multiple kinship links in one community also had dense links with another.

Of course, these observations provide a static picture. Table 7.2 suggests that there were important fluctuations in kinship densities over the course of the period 1700-1820. The strongest growth in the density of kinship links was in Bramley, which also had the most diversified economy of all six townships. Kinship densities remained strong in Horsforth, but they weakened notwithstanding rural industrialisation. In Armley, densities improved over the same period, but then fell back in the first two decades of the nineteenth century. These movements are intriguing. They confirm a very broad positive relationship between kinship densities and rural industrialisation while at the same time suggesting that a more diversified local economic structure could underpin spectacular growth in the extent and depth of kinship networks. They also suggest that kinship networks could be subjeet to tnot781526137869 
inconsiderable erosion or dilution according to local demo-economic circumstances. To take just one example, the decline in kinship density that we see in Horsforth between the late eighteenth and early nineteenth centuries is almost entirely accounted for by a two-year surge in adult and child mortality (reflecting the onset of smallpox, followed by typhus, measles, whooping cough and a fatal fire at the local fulling mill) in the late 1790s. This high mortality diluted the kinship connections of those who were related to two or more families in the locality, but it also removed the kinship connection for 29 families that had previously had a kinship link to only one further family in the locality. Within limits, then, kinship networks were physically volatile and it will be important to bear this in mind when we come to look at the welfare role of such networks. The key point though is that, by the early nineteenth century, kinship in these communities had reached virtual saturation point, testimony to a very different society from the sort that we see in Keith Wrightson's Essex or Evelyn Lord's Surrey.

Table 7.2 Kinship density over time in six West Riding towns, $1700-1820$

\begin{tabular}{lccc}
\hline Place & $1700-49$ & $1750-99$ & $1800-20$ \\
\hline Otley & 84 & 82 & 87 \\
Horsforth & 87 & 82 & 74 \\
Tong & 58 & 74 & 78 \\
Cleckheaton & 65 & 72 & 77 \\
Armley & 72 & 81 & 74 \\
Bramley & 42 & 67 & 76 \\
\hline
\end{tabular}

How did these figures manifest themselves on the ground? Every community had its core groups such as the Spacie family of Horsforth, who were related in some way or other to the majority of families in the township, and all communities also had a judicious helping of those who were just linked to one other family grouping or indeed none at all. But was there anything that particularly distinguished the kin-rich from the kin-poor? An initial observation is that the weakest kinship links were not always or indeed usually a reflection of the experience of recent in-migrants. Given substantial and growing levels of intra-township marriage and strenuous efforts on the part of migrant families to make marriage connections with more established groups in the host community, 9781526137869 
migrants often did rather well in achieving connectedness. Commentators such as Betts have observed similar features in other parts of the country. ${ }^{35}$ Nor did certain occupations have a greater tendency to generate strong kinship networks than others. Proletarianised weavers often had kinship densities on a par with substantial artisan clothiers, and they in turn often exceeded the kinship densities of local farmers.

There are, however, two factors that do mark out families with the highest kinship densities from the rest in all six communities. First, the most interconnected kinship groups were disproportionately likely by the later eighteenth century to have a substantial nonconformist character. Methodist, Moravian, Independent and Baptist circuits criss-crossed the West Riding industrial district, clearly facilitating chain migration and inter-marriage within the religious grouping, pushing up kinship densities. Second, and without exception, in all six communities families with weak or non-existent kinship networks were also families that had what we might style 'high-pressure' demography, with high marital fertility, high infant death rates and relatively low marriage ages. We will return to these characteristics later. In the meantime, the general message is clear - that kinship networks could be both extensive and of considerable depth in the West Riding.

They might also be nominally functional. Table 7.3 traces bequests made in all of the surviving wills for the six townships that could be traced at the Borthwick Institute and in local archives (where copies of wills are often preserved in family collections) between 1700 and 1820. In contrast to the picture drawn by Coster, we can see that testators in the West Riding woollen district showed no tendency to concentrate bequests on immediate co-resident family. Indeed, while Table 7.3 does not make it clear, if anything the range of kinship recognised in wills actually increased after 1750 . This may be a reflection of a lower tendency for children and other kin to leave communities as industrialisation kicked in (and hence they were more visible at the time of will-making) or it might reflect a conscious engagement with a range of kin. In the case of Bramley the evidence from the early nineteenth-century diary of Joseph Rogerson, linked to the reconstitution of the township, suggests the latter. Rogerson mentioned almost all of his available local kin (though he rarely specified an exact blood or marriage relationship) in the diary. ${ }^{36}$ 
Table 7.3 Bequests in West Riding wills, $1700-1820$

\begin{tabular}{|c|c|c|c|c|c|c|}
\hline$\overline{\text { Place }}$ & $\begin{array}{c}\text { Nuclear } \\
\text { family }\end{array}$ & Siblings & In-laws & $\begin{array}{c}\text { G'children, } \\
\text { nephews, } \\
\text { neices }\end{array}$ & Cousins & Others \\
\hline Otley & 36 & 21 & 10 & 16 & 8 & 19 \\
\hline Horsforth & 37 & 14 & 8 & 15 & 9 & 17 \\
\hline Tong & 64 & 8 & 2 & 8 & 4 & 14 \\
\hline Cleckheaton & 59 & 8 & 2 & 9 & 4 & 18 \\
\hline Armley & 52 & 12 & 4 & 11 & 7 & 14 \\
\hline Bramley & 57 & 7 & 4 & 8 & 3 & 21 \\
\hline
\end{tabular}

Source: Family reconstitutions and 452 wills drawn from the collection of the Borthwick Institute and West Riding family collections.

Note: All figures are percentages of bequests. Only those with definite (stated or from family reconstitution) kinship links are used in the table. Some 364 of the 4,200 bequests are thus omitted.

What role was there, then, for this extensive, deep and nominally functional kinship network in providing or supplementing welfare in this part of the West Riding? An initial way into this question is provided by Table 7.4 which relates kinship density and poor law spending in the six townships over the period 1750-1820. ${ }^{37}$ The table provides two index numbers for each community to ease comparison. The first takes the average density of kinship over all six communities for the whole period 1750-1820 as 100 and relates individual community kinship figures to this baseline to see if they are above or below average for the West Riding woollen district. The second takes average per capita poor law spending (to allow for different population sizes) in all six communities for the period $1750-1820$ as 100 and relates per capita spending in the individual communities to this baseline to show whether they are above or below average. ${ }^{38}$ We can see clearly that there was a broad relationship between above average kinship density and below average poor law expenditure. ${ }^{39}$ Of course, there are many ways to read this table. A limited rate base may have constrained the supply of welfare through the poor law and thus forced families to fill the gap. Alternatively, poor law officials may have consciously restricted welfare supplies to force families to step into the breach. Or the poor law may have found itself as a fallback to kinship action, coping with extreme problems or reacting to short-term changes of circumstance which overwhelmed the coping abilities of kinship networks.

Some guidance on how we might read the situation isappovided 9781526137869 Down loaded from manchesterhive.com at 04/26/2023 01:30:07PM 
Table 7.4 Kinship density and poor relief spending in six West Riding communities, 1750-1820

\begin{tabular}{lcc}
\hline Place & Index of kinship density & Index of spending relief \\
\hline Otley & 110 & 79 \\
Horsforth & 101 & 96 \\
Tong & 99 & 108 \\
Cleckheaton & 97 & 116 \\
Armley & 100 & 99 \\
Bramley & 93 & 126 \\
\hline
\end{tabular}

Note: Mean kinship density $=77$ per cent, indexed at 100 . Mean per capita poor relief spending was 30s., indexed at 100.

by Table 7.5 , which, for the period 1750-1820, contrasts the index of kinship used above with an index of monthly pension payments (the average monthly pension payment over all six communities representing 100) and an index of the percentage of the population in receipt of relief (the proportions of the population on relief in the six communities in 1801, 1811 and 1821 representing 100). Below average poor law spending in communities with higher kinship densities clearly represents both fewer people on relief at any given time and lower mean relief payments for those who did obtain relief. Again, the meaning of this table is not unambiguous, but I think that what we see here could be kinship support limiting the role of the poor law in some communities and its absence extending the role of the poor law in others, as Laslett and others have suggested. Vestry records for Horsforth ${ }^{40}$ provide some credence for this speculation. Between 1780 and 1802, the vestry received 474 applications for relief from those who had no kin or were linked to just one other family and they accepted over 90 per cent of these applications. By contrast they received 121 applications from those that we might style 'kin-rich' and they turned down 66 of them. Only cases which concerned individual and family illness seem to have been worthy of support. Some of this willingness to turn down applicants with kin represents religious tension between an anglican vestry and a group of 'kin-rich' people who were disproportionately nonconformist, but there was clearly an expectation that kin would provide welfare support in this community. 
Table 7.5 Kinship density, monthly pensions and percentage of the population in receipt of poor relief, 1750-1820

\begin{tabular}{lccc}
\hline Place & $\begin{array}{c}\text { Index of kinship } \\
\text { density }\end{array}$ & $\begin{array}{c}\text { Index of pensions } \\
\text { Index of \% on } \\
\text { relief }\end{array}$ \\
\hline Otley & 110 & 81 & 83 \\
Horsforth & 101 & 93 & 95 \\
Tong & 99 & 104 & 100 \\
Cleckheaton & 97 & 110 & 108 \\
Armley & 100 & 99 & 98 \\
Bramley & 93 & 121 & 129 \\
\hline
\end{tabular}

Note: Mean kinship density $=77$ per cent, indexed at 100 . Mean pension payment $=5$ s., indexed at 100 . Mean percentage on relief $=5.6$, indexed at 100 .

Certainly, an extensive welfare role for kin makes sense when set against other evidence from this part of the West Riding. It is clear, for instance, that even in the nineteenth century, as lunatic asylums and workhouses proliferated, relatively few of the lunatic poor from the West Riding actually ended up in them. Poor law records suggest that a combination of community and family action came to the rescue of some of the lunatic poor, but, for others, family care must have been the first and only alternative. ${ }^{41}$ An extensive welfare role for kin also makes sense when set against the wider communality and reciprocation that we can see in this area of the West Riding. Thus Mr Hainsworth reported to the 1806 committee of enquiry into the state of the woollen industry that

Some master clothiers, when the trade has been bad, would work for other masters, and they have given on another work ... the clothiers belonging to our own place of course we employed first in order to keep down the rates ... You mean that some of the masters have worked for hire? Yes, when trade has been bad they have taken goods to make for other masters, in order to keep their families by their labour. ${ }^{42}$

This said, it would be wrong to imply from this aggregate analysis simply that dense kinship links reduced poor relief bills and gave the poor law a fallback role. To draw more definitive conclusions, we need to know the nature of the kinship relationships of the individuals who received relief and to understand in rathenrmore 9781526137869 
depth the wider economy of makeshifts in which they were engaged. Nominal linkage between reconstitution data and poor law and charity accounts can provide the bedrock for this sort of deeper investigation.

What, then, was the kinship status of those who received relief? At individual level things are not as clear-cut as the aggregate analysis would imply. As we would expect on the basis of the discussion so far, many recipients of poor relief lacked kin. However, others were tied into very extensive kinship networks, as we might perhaps also expect from the work of Hollen Lees, Thane and King which stresses that the poor law sought to generate a resource partnership with kin to cope with individual level destitution. While we could draw detailed examples from all of the communities, the situation in Bramley perhaps best illustrates this latter point. Table 7.6 attempts to categorise poor relief recipients for the period 1780-1820 according to the depth of their kinship links, and we can see that three of the most well-connected people in the township appear on the relief lists. This confirms that risks of poverty were widely distributed throughout early modern communities. It might also be read as suggesting that kinship networks were unable to cope with certain sorts of need - the communitywide crises which plunged some or all of the family members into penury and which were particularly characteristic of the period 1780-1820, or perhaps even sudden crises linked to illness.

Table 7.6 Poor relief recipients and their kinship links: Bramley, $1780-1820$

\begin{tabular}{lcc}
\hline Kinship depth & Absolute number & \% of claims \\
\hline Related to $7+$ & 3 & 1.0 \\
Related to 5-7 & 8 & 2.6 \\
Related to 3-5 & 21 & 7.0 \\
Related to 1-3 & 38 & 12.6 \\
Related to 1 & 92 & 30.6 \\
Related to 0 & 84 & 46.2 \\
\hline
\end{tabular}

Note: Total number of claims (902) includes 54 for which no definitive kinship relationship could be established in the reconstitution.

Figure 7.1 gives more clarity to these ideas. It categorises poor relief recipients according to both the depth of their kinship network and the length of time spent on relief and highlights the fact that while well-connected people did get relief (and in Bramley $_{781526137869}$ 


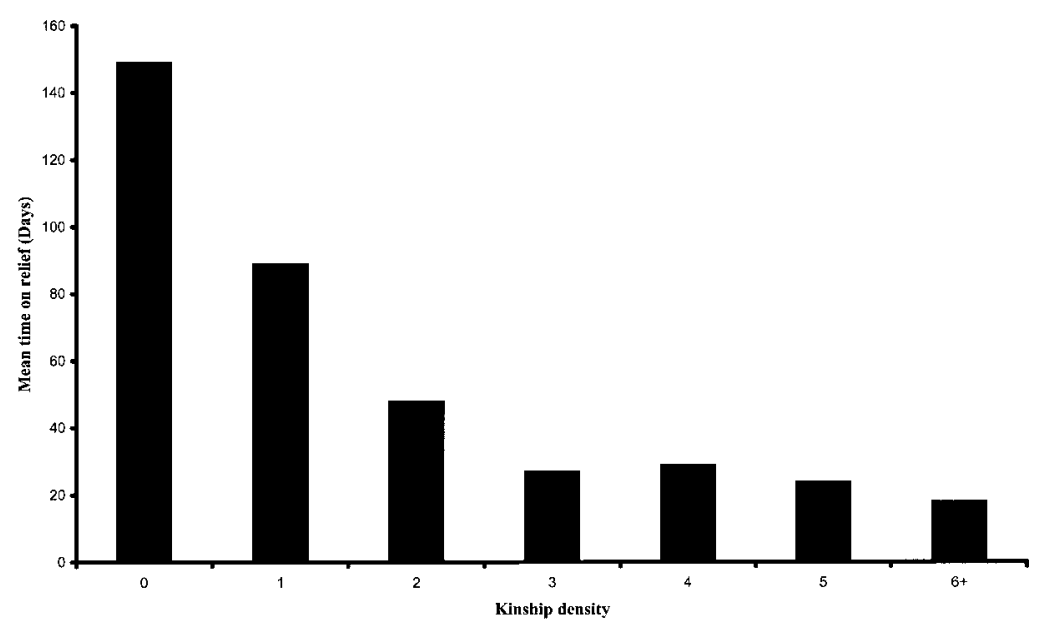

Figure 7.1 Length of time on relief and kinship depth

and the other townships well-connected people also record the top ten biggest individual or family payments of poor relief) the least well-connected people in the township stayed on relief longest. This is consistent with the situation identified by King in the nearby parish of Calverley, and with the case studies used by Fissell around Bristol. ${ }^{43}$ It seems, then, that being well connected could prompt overseers and vestries to allocate substantial shortterm payments to meet sudden need, but made it less likely that individuals would need (or the poor law would support) a longerterm relationship with the welfare system. Those with less kin or no kin found themselves in a longer-term relationship with the communal welfare system, both because of their lack of kinship and because of their high pressure demography. The poor law in Bramley was not resource starved, but might be said to adopt a conscious policy of working with kin to optimise kinship support of the needy. This is precisely what Thane and other commentators have suggested.

Meanwhile, still concentrating on Bramley, we can also see a difference in the type of relief given to those with strong kinship links compared to those with weak ones. Figure 7.2 demonstrates a clear tendency in Bramley (followed more or less clearly in all of the other townships analysed here) for late eighteenth-century sickness relief or 'investment' payments to be the focusaforthose 9781526137869 




Figure 7.2 Payment type and kinship links in Bramley

with rich kinship networks, while pensions and irregular cash payments were the primary focus for those without. There are several potential readings of this evidence, but it seems clear to me that the immediate onset of sickness (often manifested at family rather than individual level) disproportionately underpinned the application of the 'kin-rich' for poor relief and that poor law authorities were willing to provide such relief (as they did in Horsforth) until kinship and religious care networks could mobilise people and resources to cope with the situation.

Yet we should beware of lumping people together into the simple categories 'kin-rich' and 'kin-poor', as Table 7.7 begins to suggest. Using a system of index numbers, this table measures the degree to which families with certain kinship characteristics were over- or under-represented amongst those on poor relief. It takes the kinship systems in force in all six communities in 1811 (chosen because we have supplementary listings to the census data for four communities in this year ${ }^{44}$ ) and allocates families to one of several typologies. ${ }^{45}$ The classification exercise is repeated for families on poor relief in 1811 and by indexing the numbers in each typology amongst poor families against the 'expected' numbers in each typology based upon mean presence in the wider community, we can see whether certain types of kinship situation were over-represented (and hence have numbers above 100), under-represented (and hence have numbers rbelow 781526137869 
100) or exactly represented (and hence have 100 as an entry) amongst those who received poor relief. What we see is the expected over-representation of those without kin in the poor law accounts. However, there was also a very strong tendency for individuals and families without living male relatives on the father's side to appear in the relief system, whatever the exact nature of the residual kinship network. Paradoxically, though, the most important male relatives in predictive terms were not fathers, but uncles or brothers. Those without these kinship links were disproportionately likely (compared to their wider presence in the six townships) to appear on poor relief, and to stay there for some time. Of course, Table 7.7 does not prove unequivocally that uncles and brothers were disproportionately likely to offer material support to pauperised relatives, but diary evidence of functional kinship links between poor relatives and these two groups in other regions is substantial. ${ }^{46}$

Table 7.7 The over- and under-representation of kinship typologies amongst those on relief in six West Riding communities, 1811

\begin{tabular}{lc}
\hline Typology & Presence index \\
\hline Without any local kin & 174 \\
With kin of all kinds & 55 \\
Without father & 103 \\
With/without father and without immediate male kin & \\
on father's side & 139 \\
Without mother & 90 \\
Without kin on mother's side & 100 \\
With female kin only & 84 \\
With distant kin only & 110 \\
\hline
\end{tabular}

We return to this question of kinship functionality amongst those who received poor relief shortly, but a chapter attempting to locate the importance of kinship in the economy of makeshifts must also be concerned with those who did not get poor relief as well as those who did. This group comprises two sub-groups: those who applied for poor relief but were refused (whether or not they subsequently managed to get the local poor law officials to agree with them) and those who never applied for poor relief. The groups were by no means distinct when we consider life-cycles as a whole, but for the moment this categorisation is a convenient fiction. In common with almost all studies, data on the firstancategory 9781526137869 
(such as vestry records or pauper letters) are not common, while data on the second category of person are positively scarce.

Let us concentrate first on those who were turned down for relief and the state of their kinship relations. While partial vestry records survive only for Horsforth, Tong and Otley ${ }^{47}$ and for the period 1783-1811, a brief analysis of the decisions taken by these vestries is instructive. By the later eighteenth century around 15-20 per cent of those who applied to the poor law were denied relief in the three townships, with a strong tendency to employ moral criteria in making decisions on relief applicants. There is not the space here to deal with the sentiments employed by the vestries, but because we have reconstitution evidence available what we can do is to say something about the kinship relationships of those denied relief. The complex tabular results of this linkage exercise can be found elsewhere; 48 two particular observations might be made, however. First, and perhaps not surprisingly given the conclusions drawn above, those with good kinship connections on the male side were disproportionately likely to be turned down for relief. Second, individuals and families whose kinship connections were dense through marriage rather than blood were also disproportionately likely to be turned down. There are many potential interpretations of this experience, but one might be that poor law authorities were less likely to enter into resource partnerships with diluted than with tight kinship networks. In particular, it might be the case that poor law authorities liked to deal with an unchallenged authority figure, a character frequently missing from kinship networks extended through marriage. More work in this sort of vein needs to be done before we can draw any more definitive conclusions.

Meanwhile, discerning the kinship relations of those who were poor but did not apply for poor relief is a thorny problem. Tom Arkell suggests that for any community it is possible to assemble a range of measures of need in addition to the normal poor law accounts. ${ }^{49}$ One of his measures is those who pay no rates but who also do not (at the same point in time) receive poor relief. Unfortunately, contiguous rate and poor relief data exist for only three of the six townships (Horsforth, Tong and Bramley ${ }^{50}$ ) and for the period 1760-83. A brief consideration of this data reveals that almost 20 per cent of all people in the three townships paid no rates but received no poor relief, testimony to the existence of a considerable poor underclass..$^{51}$ Table 7.8 makesm mhore $^{t}$ use $^{781526137869}$ 
of the data, and we might draw two key lessons from it. First, that those on the margins of poverty were moderately connected to wider kinship networks. Second, that it was not at all unusual for a substantial ratepayer to have relatives in the poor underclass in the same township and at the same point in time. In one sense there is nothing particularly surprising about the latter observation in particular. If non-ratepayers were just solvent enough to escape the clutches of the poor relief system then relatives, even richer relatives, may have been unwilling to make transfer payments (other than perhaps to forgive debts already contracted) or may not have been called upon. Yet we could turn this idea on its head and suggest that transfers of resources or people between richer and poorer households within a defined kinship group was what kept non-ratepayers from the clutches of the welfare system in the first place. Such was the case for Nathaniel Hargreaves, who petitioned the Horsforth vestry for relief in 1789, noting that his uncle had paid his rent for the last two years 'but his long illness now means that he has much need of his purse at present'. 52

Table 7.8 Kinship characteristics of non-ratepayers and non-relief recipients in six West Riding townships, 1760-83

\begin{tabular}{lcc}
\hline Kinship depth & Absolute number & \% of non-ratepayers \\
\hline Related to 7+ & 32 & 5.9 \\
Related to 5-7 & 54 & 9.9 \\
Related to 3-5 & 104 & 19.4 \\
Related to 1-3 & 192 & 35.4 \\
Related to 1 & 86 & 15.8 \\
Related to 0 & 74 & 13.6 \\
\hline
\end{tabular}

Another way into the question of the kinship relationships of those who did not get poor relief, and also a way into the question of the value of kinship links in material terms, is to look at the overlap between those who received poor relief and those who received formal charity, and to contrast the kinship depth of those who received poor relief, those who received charity and those who received both. In this exercise, we are lucky that all of the six townships under the microscope here are blessed with good survival of charity material. ${ }^{53}$ Table 7.9 attempts this sort of linkage exercise for the six townships in aggregate. ${ }^{54}$ We might draw three important conclusions from this table. 
Table 7.9 Kinship connections of charity and poor law recipients in six West Riding communities, 1780-1810

\begin{tabular}{lcccc}
\hline Receiving & Related & Related & Related \\
& to 0 & to $1-3$ & to 3-5 & $\begin{array}{c}\text { Related } \\
\text { to } 5+\end{array}$ \\
\hline Poor relief only & 1223 & 532 & 375 & 131 \\
Charity only & 156 & 242 & 394 & 189 \\
Poor relief and charity & 78 & 43 & 31 & 19 \\
\hline
\end{tabular}

First, that the overlap between those who received relief and those who received charity at the same point in time was in most townships and at most times limited. Even in late eighteenth-century Tong, the township with by far the most overlap, only 45 per cent of those who received poor relief also received charity at the same point in time. Second, the trustees of local charities were disproportionately likely to recognise the poverty and need of people with good kinship connections, and to do so over long periods. This is perhaps not surprising given the terms under which many benefactions were made, and the wider need to show respectability in order to receive charity, something which could be done by pointing to dense kinship connections. In other words, we must be interested in kinship not just for the material and emotional benefits that it might offer, but because kinship provided a gateway to other welfare avenues, something that has been insufficiently stressed in the historiography thus far. Finally, it is clear that the attitude of charity trustees towards those with and without kin was fluid. While I do not have the space to show it here, there is more than a hint from the record linkage exercise that as the nineteenth century progressed the role of charity began to change as the balance between the relative levels of charity and poor law expenditure moved decisively towards the latter. Certainly by the 1830 s, increasing numbers of those with little or no local kinship came to rely on charity. This may reflect a change in migratory patterns, the changing dynamics of local policy or a change in the nature of poor relief and need in the run up to the new poor law, but only more research will enable us to say which. What is clear is that kinship interacted in complex ways with the changing constellation of the economy of makeshifts over time.

Looked at collectively, these tables and figures generate ambiguous and complex results. The common thread, though, d $_{t}$ the ${ }_{781526137869}$ 
idea that not having kin (or not having particular sorts of kin) is an important predictor of long-term relationship with the poor law. While the high pressure demography of the 'kin-poor' may have contributed to this relationship, it was not the main driver. By contrast, having rich kinship relationships could not always keep individuals and families out of the relief system in the short term, but kin could be a very important component (presumably along with religious self-help) in the long-term welfare patchwork.

The problem with these conclusions is that they infer a strong role for kinship in the economy of makeshifts rather than showing it (or quantifying it) directly. Of course, in the absence of the contractual, legal and other data available to continental family historians even an indirect commentary of this sort is valuable and novel. This chapter has added weight to the contentions of Pat Thane, Lynne Hollen Lees ${ }^{55}$ and others that kinship must have been an important part of the welfare safety net for early modern families. It has also reinforced ideas from Fissell and King that the poor law was disproportionately a welfare system for the 'kin-poor'. But can we say more? What was the level and form of help offered by families to their needy kin? What activated kinship support, and what served to end it? Was kinship support particularly likely at certain times of life-cycle need and less at others? And who organised the transfer of material, human or emotional resources between households within a kinship network? Oral historians have begun to ask questions such as these for the twentieth century, but the early modern period offers us fewer avenues for exploration. Let us deal briefly with two.

First, the help offered to kin by Jonathan Snowden, an Armley clothier. As well as employing outworkers in several Leeds outtownships, Snowden held land in Armley, Guiseley and Calverley. In other words, he was a wealthy man and thus perhaps not as representative as one might like. This said, Snowden's surviving pocket account books ${ }^{56}$ (1770 to 1796 , with a break between 1780 and 1783) reveal that he was very well endowed with needy relatives. Between 1775 (when he started recording all of his expenditure rather than just business expenses) and 1796, Snowden appears to have made 122 gifts or loans to relatives in Armley or elsewhere. On average he disbursed twenty-six pounds per year to relatives and while it is not always easy to discern the residence of those relatives, most can be traced back to Armley. By Pelating 9781526137869 
disbursements to the life-cycles revealed in family reconstitution, we can see that Snowden made three types of payments - small 'one-off' payments before or just after the marriages of his nephews, nieces and grandchildren; periodic small payments to relatives who were overburdened with children; and more regular payments to relatives who can be identified as recipients of charity or poor relief. In other words, Snowden was disbursing resources in exactly the way that the aggregate analysis of the relationship between kinship, poor relief and charity would suggest. Interestingly, he also finances the transfer of human resources, paying for the apprenticeship of one of his nephews and buying clothes for a niece to become a servant in the household of her aunt. Snowden was clearly aware of the life-cycle stages that could throw otherwise independent people into poverty, and he appears to have acted before the onset of the constellation of influences that would trigger the slide into destitution. We thus have at least some answers to my rhetorical questions.

A second avenue of investigation confirms much of what we can learn from Snowden. Pauper letters written back to the vestries of Horsforth and Otley from townships throughout the West Riding are replete with the language of kinship support or lack of it. ${ }^{57}$ Thomas Day, for instance, wrote to the Horsforth Vestry in 1787 from Batley. He requested payment of his rent and a small regular pension, citing an inability to get work after a finger injury. However, he added that 'My family and mee has no kin in this place and wee cannot get one penny of credit'. The two were probably linked in practice as well as linguistically, highlighting the indirect importance of kinship in the economy of makeshifts. Robert Spacey, overseer of Bramley, wrote to the Horsforth vestry in 1790 on the subject of William Hornby who is in a wretched state, havinge no worke and beeing almoste blynde he has been cared for by his sister Charlotte Eastwood these years since and his board paid by Jas Hornby, but now his condicion cannot be borne no longer'. The withdrawal or overwhelming of kinship welfare support thus carried serious consequences. Other paupers looked forward to richer kinship networks and the support that they might offer. Edward Parker wrote back to Horsforth from Pudsey in 1793 asking for relief and telling the vestry that his son, John, would soon be setting up business in Pudsey and would pay back the money granted by the vestry as well as offering long-term support. In short, there was in practice, in Sexpectation 781526137869 
and in rhetoric, a considerable role for kinship support in the economy of makeshifts and in addition to the poor law.

\section{Conclusion}

To the very specific question of the value of kinship in the wider economy of makeshifts, we can perhaps draw three fairly concrete answers. First, it seems likely that kin provided direct material support, particularly in the medium and long term, allowing people to keep away from the poor relief system or to supplement income from the community. Second, it seems likely that having or not having dense kinship networks determined access to other elements of the economy of makeshifts such as, in this particular analysis, charity. Finally, while it is clear that different individuals and families would have relied on kinship support with different intensities at different stages of the life-cycle or in response to different causes of poverty, those with access to particular constellations of kin, notably male blood relatives, may have been particularly likely to turn to kin as a first rather than a last resort. We should beware of assuming, however, that an economy of makeshifts, even if it included poor relief and material support from kin, generated a consistently sufficient income for poor people. As Rose points out for nineteenth-century Nottinghamshire, 'the elderly pieced together a very meagre subsistence' 58 and others in this volume have made similar points.

\section{Notes}

1 On household size and structure see P. Laslett, 'Size and structure of the household in England over three centuries', Population Studies, 23 (1969) and idem, 'Mean household size in England since the sixteenth century', in P. Laslett and R. Wall (eds), Household and Family in Past Times (Cambridge, Cambridge University Press, 1972). On the issue of demographic constraint, see P. Laslett, 'Family, kinship and collectivity as systems of support in pre-industrial Europe: a consideration of the nuclear hardship hypothesis', Continuity and Change, 3 (1988). For regional differences, see R. Wall, 'Regional and temporal variations in English household structure from 1650', in J. Hobcraft and P. Rees (eds), Regional Demographic Development (London, Croom Helm, 1978). 
2 See J. E. Smith and J. Oeppen, 'Estimating numbers of kin in historical England using demographic microsimulation', in D. S. Reher and R. S. Schofield (eds), Old and New Methods in Historical Demography (Oxford, Clarendon, 1993). From a different angle, see M. Anderson, 'The emergence of the modern life-cycle in Britain', Social History, 10 (1985). See also P. Laslett, A Fresh Map of Life (Cambridge, Cambridge University Press, 1989), who suggests that at least onethird of women reaching age 65 would have had no surviving children. For a sceptical view of the value of microsimulation, see S. Ruggles, 'Family demography and family history: problems and prospects', Historical Methods Newsletter, 23 (1990).

3 L. Stone, Family, Sex and Marriage in England, 1500-1800 (London, Weidenfeld and Nicholson, 1977).

4 A. Gilbert, Religion and Society in Industrial England: Church, Chapel and Social Change, 1740-1914 (London, Methuen, 1976). Also K. Honeyman, Origins of Enterprise (Manchester, Manchester University Press, 1982) and R. Grassby, Kinship and Capitalism: Marriage, Family and Business in the English-Speaking World, 1580-1740 (Cambridge, Cambridge University Press, 2001).

5 D. Cooper and M. Donald, 'Households and hidden kin in early nineteenth century England: four case studies in suburban Exeter', Continuity and Change, 10 (1995). For other literature on the problems of terminology in kinship analysis, see N. Tadmor, 'The concept of the household-family in eighteenth century England', Past and Present, 151 (1996) and M. Chaytor, 'Household and kinship: Ryton in the late 16th and early 17th centuries', History Workshop Journal, 13 (1982); also O. Harris, 'Households and their boundaries', History Workshop Journal, 13 (1982).

6 B. Reay, 'Kinship and the neighbourhood in nineteenth century rural England: the myth of the autonomous nuclear family', Journal of Family History, 21 (1996) and idem, Microhistories: Demography, Society and Culture in Rural England, 1800-1930 (Cambridge, Cambridge University Press, 1996).

7 K. Wrightson, 'Kinship in an English village: Terling, Essex, 15001700', in R. M. Smith (ed.), Land, Kinship and Life-Cycle (Cambridge, Cambridge University Press, 1985).

8 E. Lord, 'Communities of common interest: the social landscape of south-east Surrey 1750-1850', in C. Phythian-Adams (ed.), Societies, Cultures and Kinship, 1580-1850 (London, Leicester University Press, 1993). See also R. Wall, 'Elderly persons and members of their households in England and wales from pre-industrial times to the present', in D. Kertzer and P. Laslett (eds), Aging in the Past: Demography, Society and Old Age (Los Angeles, University of California Press, 1995); T. Sokoll, Household and Family Among the Poor: The Case of Two Essex Communities in the Late Eighteenth and Early Nineteenth Centuries (Bochum, Verlaag fur Regionalgeschichte, 1993); idem, 'The 
household position of elderly widows in poverty: evidence from two English communities in the late eighteenth and early nineteenth centuries', in J. Henderson and R. Wall (eds), Poor Women and Children in the European Past (London, Routledge, 1994), pp. 207-24, and idem, 'Old age in poverty: the record of Essex pauper letters 17801834', in T. Hitchcock, P. King and P. Sharpe (eds), Chronicling Poverty: The Voices and Strategies of the English Poor (Basingstoke, Macmillan, 1997).

9 In part of course historiographical division on this issue reflects the fact that the welfare role of kinship has been tied up with wider theoretical and practical discussion of the general strength of early modern families. For a discussion of the positive and negative ends of the spectrum of opinion on this issue, see S. King and J. Timmins, Making Sense of the Industrial Revolution (Manchester, Manchester University Press, 2001).

10 S. A. King, Poverty and Welfare in England, 1700-1850: A Regional Perspective (Manchester, Manchester University Press, 2000).

11 See C. Pooley and S. D'Cruz, 'Migration and urbanization in north west England c. 1760-1830', Social History, 19 (1994); C. Pooley and J. Turnbull, Migration and Mobility in Britain Since the 18th Century (London, UCL Press, 1998); D. Cressey, 'Kinship and kin interaction in early modern England', Past and Present, 113 (1986).

12 M. Fissell, 'The sick and drooping poor in eighteenth century Bristol and its region', Social History of Medicine, 2 (1989) and S. A. King, 'Reconstructing lives: the poor, the Poor Law and welfare in Calverley, 1650-1820', Social History, 22 (1997).

13 Laslett, A Fresh Map of Life. See also M. Gorsky, 'The growth and distribution of English friendly societies in the early nineteenth century', Economic History Review, LI (1998).

$14 \mathrm{~L}$. Botelho, 'Aged and impotent: parish relief of the aged poor in early modern Suffolk', in M. Daunton (ed.), Charity, Self-Interest and Welfare in the English Past (London, UCL Press, 1996) and P. Thane, 'Old people and their families in the English past', in ibid, pp. 113-38. Also idem, Old Age in the English Past (Oxford, Oxford University Press, 2000). On retirement arrangements elsewhere, see T. Held, 'Rural retirement arrangements in seventeenth to nineteenth century Austria: a cross community analysis', Journal of Family History, 7 (1982).

15 L. Hollen Lees, 'The survival of the unit: welfare policies and family maintenance in nineteenth century London', in P. Mandler (ed.), The Uses of Charity: The Poor on Relief in the Nineteenth Century Metropolis (Cambridge, Cambridge University Press, 1990) and idem, The Solidarities of Strangers: The English Poor Laws and the People, 1700-1948 (Cambridge, Cambridge University Press, 1998). Also S. A. King, 'The English proto-industrial family: old and new perspectives', History of the Family, 6 (2003). 
16 S. Cavallo, 'Family obligations and inequalities in access to care in northern Italy, seventeenth to eighteenth centuries', in P. Horden and R. Smith (eds), The Locus of Care: Families, Communities, Institutions and the Provision of Welfare Since Antiquity (London, Routledge, 1998).

17 For different representations of these views, see D. Thomson, 'The decline of social security: falling state support for the elderly since early Victorian times', Ageing and Society, 4 (1984), idem, 'Welfare and the historians', in L. Bonfield, R. M. Smith and K. Wrightson (eds), The World we Have Gained (Oxford, Clarendon, 1986), idem, 'The elderly in an urban-industrial society: England 1750 to the present', in J. M. Eekelaar and D. Pearl (eds), An Ageing World: Dilemmas and Challenges for Law and Social Policy (Oxford, Clarendon, 1989) and idem, 'The welfare of the elderly in the past: a family or community responsibility', in Pelling and Smith, Life, Death and the Elderly.

18 M.A. Crowther, 'Family responsibility and state responsibility in Britain before the welfare state', Historical Journal, 25 (1982).

19 M. J. McIntosh, 'Networks of care in Elizabethan English towns: the example of Hadleigh, Suffolk', in Horden and Smith, Locus. See also T. Wales, 'Poverty, poor relief and life-cycle: some evidence from seventeenth century Norfolk', in Smith, Land, and W. Newman-Brown, 'The receipt of poor relief and family situation: Aldenham, Herts, 1630-90', in ibid.

20 M. Anderson, 'Some problems in the use of census-type material for the study of family and kinship patterns', in J. Sundin and E. Soderlund (eds), Time, Space and Man: Essays on Microdemography (Umea, Umea University Press, 1977) argues that we should not even try to construct such typologies, but should instead focus on variations in kinship patterns within communities.

21 See the contributions to S. Woolf (ed.), Domestic Strategies: Work and Family in France and Italy, 1600-1800 (Cambridge, Cambridge University Press, 1991) and A.Janssens, Family and Social Change: The Household as a Process in an Industrialising Community (Cambridge, Cambridge University Press, 1993).

22 A. G. Darroch, 'Migrants in the nineteenth century: fugitives or families in motion', Journal of Family History, 6 (1981).

23 The Birstall reconstitutions are available from the Cambridge Group for the History of Population and Social Structure or in the library of the Yorkshire Archaeological Society in Leeds: see E. A. Wrigley, R. S. Davies, J. E. Oeppen and R. S. Schofield, English Population History From Family Reconstitution 1580-1837 (Cambridge, Cambridge University Press, 1997).

24 These figures are drawn from Edward Parsons, History of Leeds and adjoining towns (Leeds, 1848) and, because they cover only the town and not adjoining hamlets, differ from figures given by other historians. 
25 S. Barrett, 'Die protoindustrielle Entwicklung und Verwandschaft in Acht Gemeinden Yorkshires (1650 bis 1837)' (unpublished PhD, University of Marburg, 1998).

26 See S. Ruggles, 'Migration, marriage and mortality: correcting sources of bias in English family reconstitution', Population Studies, 46 (1992).

27 See P. Hudson, The Genesis of Industrial Capital: A Study of the West Riding Wool Textile Industry (Cambridge, Cambridge University Press, 1986); M. Yasumoto, Industrialisation, Urbanisation and Demographic Change in England (Nagoya, Nagoya University Press, 1994); D. Gregory, Regional Transformation and Industrial Revolution: A Geography of the Yorkshire Woollen Industry (London, Macmillan, 1982).

28 Report From the Committee of the Woollen Manufacture of England With Minutes of Evidence and Appendix, 1806 (268) III (Shannon, 1968).

29 It is also important to note that each of these villages was relatively isolated - no new roads to Leeds were built before 1820 and the existing roads were notoriously narrow and winding - and that while they were junior parts of larger parishes they nonetheless remained self-governing with their own clergy, overseers and churchwardens.

30 A comprehensive list of contemporary chapels is provided by E. Parsons, The Civil, Ecclesiastical, Literary, Commercial and Miscellaneous History of Leeds, Bradford, Wakefield, Dewsbury, Otley and the District Within Ten Miles of Leeds (Leeds, F. Hobson, 1834). Bramley and Cleckheaton were particular hotbeds of Methodism and Congregationalism respectively. Full details of the parish register and Bishops Transcript locations, the treatment of gaps and other problems with the registers, and the linkage process employed in family reconstitution can be found in Barrett, 'Die protoindustrielle', appendix 1.

31 See E. Hargrave and W. B. Crump, The Diary of Joseph Rogerson, Scribbling Miller of Bramley, 1808-1814 (Leeds, Thoresby Society, 1936). Comprehensive demographic and kinship analysis can be found in Barrett, 'Die protoindustrielle'.

32 There is not the space here to report in detail the competing methods. Broadly however, the choices are between a cohort model of the sort employed in P. R. Uhlenberg, 'A study of cohort life-cycles: cohorts of native born Massachusetts women, 1830-1920', Population Studies, 23 (1969), double-counting models of the sort employed in Wrightson, 'Kinship in an English village', the iterative model reported by A. Bideau and G. Brunet, 'The construction of individual life histories: application to the study of geographical mobility in the Valserine Valley (French Jura) in the nineteenth and twentieth centuries', in Rehr and Schofield, Old and New, or simply measures of absolute and relative kinship density. For the purposes of this chapter I use the iterative model of Bideau and Brunet. I am taking no account here of the as yet inadequately specified but potentially very important kinship models advanced by Tadmor. 
33 King, 'Reconstructing'; W. Coster, Kinship and Inheritance in Early Modern England: Three Yorkshire Parishes (York, Borthwick Institute, 1993).

34 Report From the Committee, p. 16.

35 P. F. J. Betts, 'Marriage alliances, household composition and the role of kinship in nineteenth-century farming', Local Population Studies, 66 (2001).

36 Hargrave and Crump, The Diary.

37 Only after 1750 does poor law data for all six townships become sufficiently reliable to undertake the comparisons which follow.

38 These figures are calculated from: West Yorkshire Archive Service (hereafter WYAS) Leeds, 'Horsforth Churchwarden Accounts 170058'; 'Horsforth Parish Accounts, 1730-1820'; 'Overseer Accounts of Armley, 1750-1818'; 'Parish Accounts of Birstall 1740-1830'; ' Otley Churchwardens Account' and Yorkshire Archaeological Society (hereafter YAS) 'Overseer accounts of Bramley'.

39 Communities with lowest levels of relief expenditure were also those with the most intra-community marriages. It could thus be argued that, like friendly societies, the institution of considerable local inter-marriage was a reflection of weak regional poor law systems and was itself a coping system.

40 YAS, 'Vestry minutes for Horsforth township'.

41 For early work on admissions to asylums, see J. K. Walton, 'Lunacy in the Industrial Revolution: a study of asylum admissions in Lancashire, 1845-50', Journal of Social History, 13 (1979). For more recent work, see R. Adair, J. Melling and B. Forsythe, 'Migration, family structure and pauper lunacy in Victorian England: admissions to the Devon county pauper lunatic asylum 1845-1900', Continuity and Change, 12 (1997). D. Wright, 'Familial care of idiot children in Victorian England', in Horden and Smith, Locus, adopts a more sceptical view of the role of the family in the nineteenth century. A. Suzuki, "The household and the care of lunatics in eighteenth century London', in Horden and Smith, Locus, echoes these concerns suggesting that lunatic children were often forced out of the household and into dependence upon the community at life-cycle pressure points such as old age of parents or the birth of new children in younger families.

42 Report From the Committee, p. 8.

43 King, 'Reconstructing'; Fissell, 'The sick'.

44 Detailed in Barrett, 'Die protoindustrielle', 376-89.

45 Of course, families which showed multiple characteristics had to be allocated according the best guess yardsticks, but the vast majority of families slotted more or less easily into my categories.

46 See for instance the help afforded to his brother and his nephews and nieces by the Lancaster merchant William Stout: J. D. Marshall, The Autobiography of William Stout of Lancaster, 1665-1752 (Manchester, 
Manchester University Press, 1969). The Coventry ribbon weaver Joseph Gutteridge also notes a cash injection by his brother 'from his own limited store' to the Gutteridge household at a time of economic crisis: see V. Chancellor (ed.), Master and Artisan in Victorian England: The Diary of William Andrews and the Autobiography of Joseph Gutteridge (London, Mckay, 1969).

47 WYAS Leeds: 'Horsforth township minutes, 1779-1821'; 'Minutes of the 24 men of Tong, 1783-1811'; 'Otley vestry minutes 17501832'.

48 Barratt, 'Die protoindustrielle', pp. 274-99.

49 T. Arkell, 'The incidence of poverty in England in the later seventeenth century', Social History, 12 (1987).

50 WYAS Leeds: 'Horsforth parish book'; 'Tong rate assessments 1672 1837'; YAS 'Bramley rate lists, 1666-1857'.

51 Of course, most of these people would subsequently go on to claim relief, or had done so in the past, but this is not the point at issue here.

52 YAS D/1/23/3, 'Pauper letters'.

53 WYAS Leeds: 'Popplewell Charity Accounts'; 'Hainsworth Charity'; 'Returns of the Hainsworth Charity', 'Horsforth Township Book'; 'Sir Walter Calverley Charity Accounts'; 'Cleckheaton Township Records'; 'Shuttleworth Charity'; 'Hargeaves Charity Accounts'.

54 We should beware of concentrating too much on exact figures as opposed to order of magnitude. Cross-source and cross-period record linkage of this sort is notoriously difficult, and up to one-fifth of the links on which the figures are based might be termed 'best guess'. Since linkage errors are likely to be randomly distributed, concentrating on orders of magnitude should blunt the force of this problem.

55 Thane, 'Old age'; Hollen Lees, Solidarities.

56 I am grateful to Ruth Snowden for the use of this book from her family collection and for bringing it to my attention when I talked in Leeds.

57 YAS D/1/23/3, 'Pauper letters'.

58 Rose, 'Widowhood', p. 287. 